Magdalena Szczyrbak*

\title{
I'm thinking and you're saying: Speaker stance and the progressive of mental verbs in courtroom interaction
}

https://doi.org/10.1515/text-2019-0145

Received February 15, 2019; accepted January 13, 2021;

published online February 2, 2021

Abstract: This study investigates the use of progressives with mental verbs in courtroom talk and shows a range of subjective meanings which are not delivered by the simple form. Looking at the data from a British libel trial, it explores patterned co-occurrences with first-person subjects vs. second- and third-person subjects, revealing both emphatic, polite and interpretative uses of the analyzed items. In addition, context-sensitivity and speaker status (judge vs. other participants) are shown to be significant factors affecting both the choice of verbs and their interactional configurations. The findings reveal not only well-established uses of "progressive statives" (wonder and think) but also less conventional ones which convey intensity and expressivity (e.g., understand, remember and want). It is also revealed that the use of progressives with mental verbs differs from the deployment of progressives with communication verbs. In both groups of verbs, however, the interpretative meaning is common. In sum, the study situates progressives with mental verbs among stancetaking resources which speakers employ to share their thoughts, wishes and desires, and to position themselves against other interactants and their propositions.

Keywords: communication verbs; courtroom discourse; mental verbs; progressives; stance; subjectivity.

\section{Introduction ${ }^{1}$}

The past few decades have seen a great deal of interest in contextual analyses of the progressive construction, with corpus-based studies revealing its increased

1 This article is based on the talk "Speaker stance and the progressive in courtroom interaction" delivered on November 1, 2018 during the "Pragmatics in the law" workshop at the fourth

*Corresponding author: Magdalena Szczyrbak, Institute of English Studies, Jagiellonian University, al. Mickiewicza 9a, 31-120 Kraków, Poland,

E-mail: magdalena.szczyrbak@uj.edu.pl. https://orcid.org/0000-0002-0182-0938

Ә Open Access. ( 2021 Magdalena Szczyrbak, published by De Gruyter. (c) BY under the Creative Commons Attribution 4.0 International License. 
frequency and new patterns of use. Some attribute this rise to people's desire "to make what they say more lively and vivid” (Potter 1975: 120 in Römer 2005: 22) while others regard it as a sign of the ongoing "colloquialization" or, possibly, as “a grammatical phenomenon” (Mair and Hundt 1995: 118 in Römer 2005: 22). Whatever the reasons for the new trend, the progressive form, in its various guises, is now linked to several new functions. These, as has been noted, are invariably tied to the speaker's perspective and its manifestation in discourse. As a result, subjective uses of the progressive have been the focus of numerous analyses, some of which address its role in informal conversation (Freund 2016), media discourse (Levin 2013) or political speeches (Martinez Vazquez 2018).

The study reported here, in turn, looks at courtroom data to show how patterns with mental verbs, which typically do not attract the progressive form, instantiate both tentative and emphatic modes of expression reflecting the subjectification of various language structures (Traugott and Dasher 2002). It specifically explores patterned co-occurrences with first-person subjects vs. second- and third-person subjects, revealing both emphatic, polite and interpretative uses of the analyzed forms. The study situates progressives among stancetaking resources which speakers employ to position themselves against other interactants and their propositions, even though, admittedly, their frequency in courtroom discourse is rather low. Still, it is argued here that the progressive construction is a vehicle for subjective meanings which are not delivered by the simple form of verbs.

Of particular interest to the current investigation is the "interpretative" (Huddleston and Pullum et al. 2002) or "experiential” (Wright 1995) progressive, conveying the speaker's epistemic stance at a particular moment or his/her "interpretation or evaluation of some state of affairs" (Wright 1995: 156). The use of this form in courtroom talk, and especially its co-occurrence with communication verbs, has featured in several investigations (Szczyrbak 2016, 2018). On the other hand, progressives of mental verbs, whose role in courtroom examinations may seem marginal, have not attracted much attention. Therefore, in the current analysis, I look at patterns with such progressives, hoping they will illuminate how participants in courtroom proceedings use them for intersubjective positioning in the discursive process of making evidence. The aim of the study is threefold: 1) to identify progressives of mental verbs in the data and determine their role in marking speaker stance; 2) to identify differences, if any, in the pragmatic functions of progressives of mental verbs with first-person subjects vs. second- and

International Conference of the American Pragmatics Association (AMPRA-4) organized by the University at Albany, State University of New York. The original material has been reworked and extended. 
third-person subjects; and 3) to compare patterns with such progressives and their pragmatic functions with those of progressives of communication verbs.

The remainder of the article is organized as follows. Section 2 introduces the notions of subjectivity, subjectification and stance as well as offers an overview of the literature on the subjective uses of the progressive. Section 3 describes the data and explains the theoretical background of the study. Section 4 looks at examples of the progressive of mental verbs in the data and compares them with earlier findings on the progressive of communication verbs. Section 5 closes with a discussion and conclusions.

\section{Literature review}

\subsection{Subjectivity and speaker stance}

Language is hardly ever neutral since it usually expresses somebody's point of view and (more or less explicit) evaluation. Linguistic subjectivity is thus "an expression an incarnation, even - of perceiving, feeling, speaking subjects", or, to put it differently, it is "the intersection of language structure and language use in the expression of self” Finegan (1995: 1-2). To identify and interpret subjective meanings in discourse, analysts apply various analytical concepts and methodological tools. Currently, there are two major strands of subjectivity research: synchronic (cognitive), represented, e.g., by Langacker (1987) and diachronic, focusing on the subjectification of language structures (see, e.g., Traugott and Dasher 2002). As for the difference between subjectivity and subjectification, the first term refers to "speakers' expression of self and the representation of perspective or point of view in discourse" whereas the latter denotes "the processes of linguistic evolution that lead to such strategies” (Finegan 1995: 1).

This study adopts the notion of stance(taking) in line with discourse-functional approaches which see it as a collaborative activity performed by co-present participants (Englebretson 2007). ${ }^{2}$ It is also believed here that "[s]tance has the power to assign value to objects of interest, to position social actors with respect to those objects, to calibrate alignment between stance takers and to invoke systems of sociocultural value" (du Bois 2007: 139). In other words, stance is located in the

2 Stance and related phenomena have been studied under various names and in different research traditions. Some of them include modality (Palmer 1986 [2001]; Nuyts 2001), evidentiality (Chafe and Nichols 1986; Aikhenvald 2004), grounding (Langacker 1987), metadiscourse (Hyland 2005), intersubjectivity (Verhagen 2005), appraisal (Martin and White 2003) and evaluation (Hunston and Thompson 2000; Hunston 2011). 
linguistic resources with which speakers express their attitudes, beliefs and assessments related to discourse objects and subjects. In the remainder of the article, I argue that the use of progressives is one of such resources.

\subsection{Subjective use of the progressive}

As already noted, context-specific behavior of the progressive has been addressed in corpus-based studies, in contrast to grammar books which foreground the imperfective-aspectual dimension of this construction and its reference to "temporary situations, activities or goings-on" (Leech 2004: 19). Relevant to the focus of the current investigation, however, are not invented examples illustrating traditional uses of the progressive, but rather empirical works documenting its novel, interactional meanings. One such investigation of spoken British English suggests that progressives have two central features - 'continuousness' and 'repeatedness' - which may be variously combined to describe actions and events (Römer 2005: 86-90). ${ }^{3}$ It also identifies seven additional functions: general validity, politeness or softening, emphasis or attitude, shock or disbelief, gradual change and development, old and new habits and, finally, framing (Römer 2005: 95). In her discussion of emphatic and attitudinal progressives, in particular, Römer (2005: 99) notes a high percentage of first-person subjects and the co-occurrence with the time adverbials always, now and all the time. She also notes that always collocates with second- and third-person subjects, and she links such instances to the speaker's annoyance or irritation. Among the verbs found in "emphasis/attitude" contexts, Römer (2005: 100) lists four mental verbs, i.e., hoping, meaning, seeing and wanting. Interestingly, the very same forms are also associated with "politeness or softening," just like thinking and wondering are (Römer 2005: 98).

Recent change in the verb phrase, including emergent patterns with progressives, has also been reported in several studies in Aarts et al. (2013). One of them concerns progressive verbs in American English and it discusses a recent rise in the BE being + ADJ. pattern (e.g., I'm being facetious) as well as the spread of the progressive to private verbs which typically resist this construction (Levin 2013). ${ }^{4}$ In addition, the increase in progressives is attributed to four factors: subjectification, democratization, colloquialization and generalization (Levin 2013: 213). Levin (2013: 213) also argues that progressives with private verbs convey subjective meaning

3 This, as proposed by Römer (2005: 90-91), gives four value combinations: 'continuous + repeated,' 'continuous + non-repeated,' 'non-continuous + repeated' and 'non-continuous + non-repeated.'

4 In the current study, this class of verbs is referred to as "mental verbs" and it encompasses, to use the terms found in Leech (2004), both "verbs of attitude" (hope, love, want) and "verbs of inert cognition" (think, know, suppose). 
components such as intensification, tentativeness and politeness, which he sees as “a prime example of subjectification" (Levin 2013: 213). Commenting specifically on the current usage of the progressive with think, he distinguishes its four main meanings: 'cogitate,' 'intend,' 'quotative,' and 'interpretative' (Levin 2013: 209). Likewise, the progressive I'm thinking features in another contribution in the same volume. In his diachronic study, Kaltenböck (2013) focuses on "main clause-like" comment clauses (e.g., I think, I suppose, I guess) and looks at their possible extension to variant forms including progressives. Based on mostly written corpus evidence from American English, he notes a rise in progressives such as I'm thinking and I'm guessing, hypothesizing that they may be taking over the epistemic meaning of $I$ think whose modal use is fading (Kaltenböck 2013: 311).

Similar observations are shared by Freund (2016), who explores stativeprogressive change in British English and who finds that progressives with think and love are salient in conversational data. Explaining the meaning of aspect, Freund (2016: 51) highlights the most significant feature of the progressive: the fact that "it is under the speaker's control." She goes on to say that speakers select "auxiliary and main verb inflections, in order to express a personal view of an event as complete, ongoing, beginning, continuing, ending or repeating” (Freund 2016: 51). For this reason, following Smith (1983: 479), she refers to the progressive as the "viewpoint aspect." At the same time, she admits that non-aspectual uses of this construction may seem problematic since they do not reflect the progressive's core meanings of “temporariness or incompletion" (Freund 2016: 52). To identify new patterns of use in informal interaction, Freund considers four semantic categories of stative verbs: relational, cognitive, affective and perceptional. Her findings reveal, however, that there is no correlation between the semantic categories of verbs and the increased frequency of certain progressives. ${ }^{5}$

A cognitive-linguistic perspective on "progressive statives" is, in turn, offered in Prażmo (2018), who in her account of the BE + -ing construction points to its core meaning of "immediacy in temporal reality" and a number of peripheral "meaning potentials" (Norén and Linell 2007). Discussing the "modal potential" of the present progressive, Prażmo (2018: 46) validly observes that some of its meanings remain underspecified and "can only be substantiated in a certain linguistic context and pragmatic environment." 6 To illustrate the "modal colouring" of progressives with

5 Interestingly, Freund (2016: 57) provides results of a survey examining acceptability of stativeprogressive combinations. In the survey, progressives with think and love received the highest approbation rate (82\%) whereas the other end of the continuum was occupied by progressives with doubt (56.9\%) and want (49.4\%).

6 In other words, they can be "pragmatically enriched and modified according to the speaker's needs" (Prażmo 2018: 46). 
stative verbs, Prażmo focuses on combinations with want, positing that they encode the speaker's doubt and uncertainty towards the proposition as well as introduce a sense of tentativeness. Thus, as she suggests, the form I am wanting results from the blending of the speaker's 'desire or wish for something' and the 'temporariness and relevance to the moment of speaking', resulting in his/her 'planning to, going to or even acting on that desire' (Prażmo 2018: 57). Taking a broader perspective, Prażmo enumerates unconventional meanings, or "extra effects" of "progressive statives" in general, suggesting that they can: 1) intensify the emotion expressed by the verb; 2) indicate current behavior as opposed to general description; 3) introduce change in states by focusing on differences in degree across time; 4) show limited duration; 5) emphasize conscious involvement; 6) show vividness; 7) express politeness; 8) mitigate criticism; and 9) avoid imposition (adapted from Prażmo 2018: 55).

Also, the cognitive view agrees with the idea that the core meaning of the interpretative progressive is contingency, i.e., clarification of a singular event which is 'not entirely obvious' and which is not applicable to other situations (cf. De Wit and Brisard 2014; Martinez Vazquez 2018). This is also in line with Nuyts's (2001:363) observation that "bringing up one's commitment, of any type, to a state of affairs in a discourse implies that the status of the state of affairs in this regard is not obvious, e.g., because the hearer turns out to hold a different view, or because there is otherwise new information relevant for one's view."

To sum up, however varied in their approaches and research foci, corpusbased analyses like those mentioned above provide ample evidence that the non-aspectual use of the progressive is spreading and that this construction conveys subjective meanings which are absent in its non-progressive counterpart. Therefore, in my view, the BE + -ing construction deserves a more in-depth analysis in a larger number of contexts, including legal genres which so far have received scant attention in this research area. To fill this gap, the study reported here explores the subjective use of the progressive in courtroom interaction and argues for its classification as a marker of stance.

\section{Data and method}

The data used in the analysis come from a British libel trial related to the portrayal of the Holocaust by revisionist historian David Irving (for a more detailed description of the trial, see Szczyrbak 2018). The analysis places itself within Corpus-Assisted Discourse Studies and adopts the distributional approach to phraseology which equates phraseological units with word combinations identified on the basis of their frequencies (Granger and Paquot 2008: 29). It also draws on Interactional Linguistics and owes its approach to spoken production to Conversation Analysis as well. It 
makes use of both quantitative and qualitative approaches to material drawn from transcribed courtroom data covering the whole of the 32-day trial (totalling around 1.5 million words). Given the limited scope of the study, 12 mental verbs, believed to be the most common ones, were selected for analysis. Thus, the list included the verbs: think, believe, wonder, guess, assume, suppose, hope, doubt, find, know, remember and want. The results of the semi-automated analysis aided by the concord function of WordSmith Tools (Scott 2012) are reported below.

\section{Results}

In total, 188 concordance lines with progressives of mental verbs were retrieved, out of which more than two-thirds turned out to be patterns with first-person subjects (132 tokens). Among the latter, 93 occurrences were present progressives whereas 39 represented past progressives. These figures clearly indicate speakerorientedness and focus on the here-and-now context of communication. Progressives with second- and third-person subjects, on the other hand, returned 56 hits, out of which 41 were present progressives and 15 represented the past form. Strikingly, in this group, no single pattern was repeated more than five times. This shows that explicit references to second- and third-person subjects' wishes, hopes and attitudes were not relevant to the ongoing interaction and so they did not form any salient patterns.

In what follows, I examine selected combinations with first-, second- and third-person subjects in detail.

\subsection{Progressives of mental verbs with first-person subjects}

Progressives with first-person subjects (Table 1) proved to be important for the overall findings as they represented more than two-thirds of the analyzed items. This agrees with earlier studies, pointing to the speaker-centeredness and the here-and-now orientation of the progressive form. In the data at hand, interestingly, speaker status emerged as a significant factor. More than half of all the subjective uses of the BE + -ing construction were identified in the judge's turns (68 tokens vs. 64 tokens found in the turns of the other speakers). It might be speculated that as an authority figure, the judge was in a position to share his own thoughts, to convey emphasis and intensity, and even to signal his lack of understanding. The remaining participants (claimant, counsel, witnesses) focused less on their emotions and chose to mark tentativeness, politeness and a lower degree of imposition instead. Likewise, the progressive form appeared 
Table 1: Progressives of mental verbs with first-person subjects.

\begin{tabular}{llll}
\hline Present progressives & & \\
\hline I am (just/really) thinking & 13 & judge (7), claimant (3), witness (2), counsel (1) \\
I am not thinking & 1 & claimant (1) \\
we are thinking & 5 & judge (3), claimant (1), counsel (1) \\
I am (just) wondering & 32 & judge (17), claimant (8), counsel (6), witness (1) \\
I am hoping & 13 & counsel (5), claimant (5), judge (3) \\
I am doubting & 1 & counsel (1) \\
I am not doubting & 1 & judge (1) \\
I am (actually/just) remembering & 2 & claimant (2) [other-reporting] \\
I am (really) finding & 7 & judge (6), claimant (1) \\
I am not (really) finding & 3 & judge (3) \\
I am understanding & 4 & judge (4) \\
I am not (quite/really) understanding & 4 & judge (3), counsel (1) \\
I am (just) wanting & 2 & judge (2) \\
I am assuming & 5 & witness (2), claimant (2), judge (1) \\
\hline Past progressives & \multicolumn{3}{l}{} \\
\hline I was (really) thinking & 10 & judge (7), witness (2), claimant (1) \\
I was not thinking & 1 & witness (1) \\
I was (just) wondering & 9 & judge (7), counsel (1), claimant (1) \\
we were hoping & 1 & claimant (1) \\
I was (still/rather) hoping & 18 & claimant (10), counsel (4), judge (4) \\
\hline Total & 132 & \\
\hline
\end{tabular}

most useful at contentious moments, when the speakers' views were being (re-) interpreted and (re-)assessed. On the other hand, the presence of modifiers (e.g., just, quite, really, actually) in some of the patterns provides further evidence that the speakers relied on progressives to perspectivize their utterances.

\subsubsection{Wonder}

With 41 occurrences, wondering emerged as the preferred progressive with the firstperson subject. Interestingly, while the present progressive often co-occurred with just (17 tokens), there was only one such co-selection with the past progressive. Predictably, I am (just) wondering referred to the speaker's ongoing mental process (1) whereas I was wondering signaled tentativeness and acted as a conventional politeness marker lowering the degree of imposition (2). In sum, it was found, progressives with wonder represented well-established uses and this may explain why they were the most frequently selected forms among the analyzed items. 
(1) [Judge] Yes, I understand the point you are trying to make. I am just wondering where you got the point from?

[Claimant] From my own common sense, my Lord.

[Judge] That is rather what I thought.

(2) [Counsel] What is the document? May we have it, my Lord?

[Judge] I am sorry?

[Counsel] I was wondering whether this document should be disclosed. I have never seen it, a quotation from a document. It may be the draft of $\mathrm{Mr}$ Irving's speech. I do not know.

\subsubsection{Think}

Another frequent progressive with the first-person subject was, as might be expected, the progressive with think. According to the existing research, the functions of I'm/I am thinking vary greatly depending on the discourse type (Levin 2013; Martinez Vazquez 2018). In the courtroom data analyzed here, three meanings were distinguished: 1) 'cogitate'; 2) 'hold an opinion'; and 3) 'interpretative.' The first of the three uses expresses the "activation or arousal of thought processes", which is “equivalent to 'considering' or 'ruminating”" (Leech 2004: 29). As such, it points to the subject being in control of a mental process at a particular point in time.

This use was most prominent in the data, and it was identified both in present and past progressives. In example (3), for instance, the judge refers to his thought processes while seeking to win the hearer's positive regard for his way of thinking with you know. The second type of progressive, in turn, similar to deliberative I think that, acts as an opinion marker. ${ }^{7}$ In the data, there was only one such example (4), in which the speaker's preferred argument was preceded by yes marking agreement with the judge's stance. The third, "interpretative," use may well be paraphrased by 'I mean' and it resembles, e.g., the interpretative progressive with think found in political speeches (Martinez Vazquez 2018). ${ }^{8}$ Worthy of attention in this context is

7 The data yielded one example of the progressive with think followed by the that-complementizer. By analogy to I think that (see Aijmer [1997: 21]; Wierzbicka [2006: 38]), I am thinking that also seems more deliberative than its that-less variant.

8 In her corpus-based study, Martinez Vazquez (2018: 115) notes the cohesive role of I am thinking which in her data is used to clarify a preceding segment of discourse ('interpretative' use) or to talk about a situation prior to the time of speaking, making it more vivid ('narrative' use). 
preposition dropping noted both in present and past progressives (5). ${ }^{9}$ Also, several past progressives with think followed the $I$ was thinking simply/more/actually of pattern associated with clarification, as shown in (6).

(3) [Judge] That is probably best. Anyway, I have given the hint yet again. Mr Rampton is going shortly to ask me to make a ruling about it and, if I have to make a ruling, you know the way I am thinking at the moment, so let us get on.

(4) [Judge] No. All I think is that sometime that is relevant.

[Counsel] It is obviously important.

[Judge] Both to the manipulation and also to Auschwitz.

[Counsel] Yes. I am thinking that the subject of Hitler's Adjutants is a long one with, I am afraid, probably quite a lot of documents to look at because of the records of what they said. That may take more than one day, which I do not have, so I was going to leave that until after Auschwitz.

(5) [Counsel] He wants to go back home to America. So if he is not finished tomorrow, which is Tuesday, I would ask that he could be finished on Wednesday morning.

[Claimant] I was thinking Wednesday morning, yes.

(6) [Claimant] The eyewitnesses?

[Judge] Well, I was thinking more of the camp official eyewitnesses, but take them, and I think there are probably about 10 or maybe a dozen of them, something like that.

\subsubsection{Hope}

Apart from the patterns discussed above, the data provided evidence of progressives with hope, a common desire operator representing volitive modality. Like other "verbs of attitude" (e.g., love, want) - alternatively referred to as "anti-progressive" (Leech 2004) - hope can turn from a static verb into a dynamic one once it is combined with the progressive form. Because of this, it can convey dynamism and a higher degree of intensity or expressivity, which is not delivered when the simple

9 Freund (2016: 58) also identified preposition dropping after I'm thinking in informal conversational data. However, in her dataset the pattern was realized as a list of three or more items preceded by I'm thinking (e.g., I'm thinking pub, no speeches, no first dance, around forty people and some decent grub.). In such instances, the speaker visualized a future event while expressing some uncertainty. In my dataset, no such uses were attested. 
form is used (cf. De Wit and Brisard 2009: 15). As could be observed in the data, the person who tended to stress their wishes and desires most was the claimant (16 tokens), although some instances were identified in the turns of the counsel and the judge as well. Apparently, the witnesses felt no need to highlight their personal wishes and desires, and so progressives with verbs of attitude were not found in their turns.

Furthermore, the witnesses' responses were more restricted as they were related to the "secondary reality" of the courtroom (the disputed actions and events) and not to the "primary reality" (the proceedings themselves) (cf. Gibbons on police interviews [2005: 142-150]). As regards its syntactic realizations, I was hoping was followed by the zero or that-complementizer, or by the to infinitive, and there was no evidence of its parenthetical use. As examples (7) and (8) demonstrate, progressives with hope - which were sometimes followed by negation - indicated the speaker's most immediate wish anchored in "temporariness" rather than a long-term desire, and they conveyed a greater level of intensity than would have been expressed by the simple form $I$ hope. ${ }^{10}$

(7) [Claimant] It helps on numbers, my Lord, because we have numbers of items that had been collected from the victims by April 30th 1943.

[Judge] It does not say "from when".

[Claimant] I am hoping that the witness will assist us on this.

(8) [Claimant] I am very familiar with what Mr Rampton is trying to get out of this case, my Lord.

[Judge] Do not worry about what he is trying to get out of the case. I want to make sure that I know where we going with the cross-examination.

[Claimant] I will put my cards face up on the table then, which I was hoping not to have to do as early as this in the cross-examination.

\subsubsection{Understand}

A brief note on progressives with understand also seems relevant to the discussion, although in the data there were only eight co-occurrences with first-person subjects and barely one co-occurrence with a second-person subject. As a cognitive

10 Černá (2014: 117) notes a difference between the polite uses of I hope and I'm hoping, saying that the simple form is preferred when the listener is invited to do something to his/her advantage whereas the progressive form is more appropriate when the request puts the listener to inconvenience. This seems to tie in with the co-occurrence of I'm/I was hoping with negation. Černá (2014: 117) also observes a correlation between the length of the request and its complexity, noting that longer forms tend to be more polite. 
verb reflecting an "intellectual state," understand - similarly to believe, know and realize - still resists the progressive (unlike think found in the same category). When combined with the progressive form, however, it conveys emphasis and adds expressivity (cf. De Wit and Brisard's [2009: 15] “connotation of intensification”). As can be seen in example (9), the judge uses the progressive form of understand to stress his lack of understanding of the evidence at hand while mitigating the force of this statement with I am afraid and not really. In example (10), in turn, the counsel stresses his confusion as to which entry in the Goebbels' diaries is the subject of the ongoing discussion.

(9) [Judge] (...) I am afraid I am not really understanding the footnote crossreferences. Am I going to be provided with them or not? That was a question.

(10) [Counsel] Sorry, I am not understanding, but I thought we had, unless I have gone completely mad, a discussion this morning about the entry for 13th December 1941?

\subsubsection{Remember}

Finally, example (11) contains the interpretative use of the progressive with remember embedded in a reporting utterance. Here, the claimant offers his own reading of the written evidence presented in court, producing his interpretation (rather than a verbatim report) of another witness's account, with the modifiers actually and just introducing a contrast between what, in the speaker's view, is real/factual and what is doubtful. In this instance, the progressive with remember may well be replaced by the progressive with recall, both of which indicate "animate agency" (Leech 2004: 28). ${ }^{11}$ This is the only example of the interpretative progressive in the data in which the speaker adopts the $I$-perspective to represent another party's standpoint. ${ }^{12}$

11 According to Prażmo (2016: 175), in some contexts, the progressive with remember may also convey the meaning of 'paying tribute to someone,' as her online data indicate (e.g., Today, I'm remembering our nation's fallen heroes [...]). In the courtroom context, such meanings were not identified.

12 Other examples include third-person subjects referring to non-present witnesses' accounts, as in here he is remembering it in June 1947 or does this strike you as being something that he is really remembering? These examples may also be classified as "narrative" (Martinez Vazquez 2018) since they show the relevance of past events to the ongoing discourse and make them more vivid (cf. the "historic present" in Quirk et al. [1985: 181]). 
(11) [Claimant] Are you familiar with the passage where Eichmann, challenged about a particular episode, interrupted the interrogator 2 min later and said words to this effect: "I am sorry. You asked me 2 min ago about that episode, and I have to say now I cannot remember whether I am actually remembering it or just remembering being asked a question about it more recently"?

\subsection{Progressives of mental verbs with second- and third- person subjects}

Although less frequent than the progressives discussed in Section 4.1, progressives of mental verbs with second- and third-person subjects in their own way contributed to the co-construction of meaning and, thus, the discursive making of evidence (Tables 2 and 3). Half of these forms (28 tokens) included third-person subjects who did not participate in the ongoing interaction and who, therefore, belonged to the "secondary reality" of the courtroom, revived through the accounts provided by the co-present speakers (cf. Section 4.1). This effect was achieved due to the interpretative progressive describing third parties' purported convictions and beliefs. On the other hand, patterns with second-person subjects tended to co-occur with the volitive modality markers want and hope (15 tokens). Modifiers such as really or just were attested as well, but they were used rather sporadically.

\subsubsection{Think}

In the group of progressives with second- and third-person subjects, patterns with think were quite visible (13 tokens). Their role in discourse differed, however, from the functions associated with first-person subjects. Some of these progressives, it was found, were interpretative (12) while others exemplified the conventional thirdperson reference typical of institutional contexts (13). Contrary to what was observed in patterns with first-person subjects, invocation of second-person subjects' thoughts and beliefs did not appear relevant and it was not very common. ${ }^{13}$

13 This is in stark contrast with the distribution of progressives of communication verbs with second-person subjects. Interrogatives such as are you saying/suggesting/telling us are frequent in courtroom examinations and, as argued in Szczyrbak (2018), they are part of the "courtroom idiom." 
Table 2: Progressives of mental verbs with second-person subjects.

\begin{tabular}{lll}
\hline Present progressives & & \\
\hline you are thinking & 1 & witness (1) \\
are you thinking & 1 & judge (1) \\
you are hoping & 5 & counsel (3), claimant (2) \\
you are finding & 3 & judge (2), witness (1) \\
you are quite understanding & 1 & judge (1) \\
you are wanting & 4 & judge (4) \\
are you (really) wanting & 3 & judge (3) \\
are you assuming & 1 & judge (1) \\
you are assuming & 3 & claimant (1), judge (1), witness (1) \\
\hline Past progressives & & \\
\hline were you wanting & 1 & judge (1) \\
you were wanting & 2 & judge (2) \\
you were (just) assuming & 2 & judge (1), claimant (1) \\
you were assuming & 1 & judge (1) \\
\hline Total & $\mathbf{2 8}$ & \\
\hline
\end{tabular}

Table 3: Progressives of mental verbs with third-person subjects.

\begin{tabular}{lll}
\hline Present progressives & & \\
\hline judge/Lordship/person/Rampton is thinking & 4 & claimant (4) \\
they are thinking & 3 & claimant (3) \\
he is doubting & 1 & counsel (1) \\
he is not doubting & 1 & judge (1) \\
people who are believing & 1 & witness (1) \\
nobody on this side of the court is supposing & 1 & counsel (1) \\
he is (really) remembering & 3 & claimant (3) \\
they are finding & 1 & witness (1) \\
he is not wanting & 1 & judge (1) \\
they are obviously assuming & 1 & claimant (1) \\
he is not assuming & 1 & claimant (1) \\
the court is not assuming & 1 & claimant (1) \\
\hline Past progressives & & \\
\hline he was thinking & 1 & witness (1) \\
Hitler really was thinking & 1 & judge (1) \\
they were thinking & 2 & claimant (1), witness (1) \\
the Defence were hoping & 1 & claimant (1) \\
Hitler was hoping & 1 & claimant (1) \\
he was wanting & 1 & claimant (1) \\
Hitler was wanting & 1 & judge (1) \\
Jewish communities were assuming & 1 & witness (1) \\
\hline Total & $\mathbf{2 8}$ & \\
\hline
\end{tabular}


(12) [Claimant] Yes, usually there is a line above the table talks saying who is present as the guests of honour. Usually three or four people are listed. Verna Kopen did the same in his records of the table talks.

[Judge] I am a bit puzzled about this, because if you interpret the table talk as meaning that Hitler really was thinking only in terms of deportation, I know it has been a long day, but how do you reconcile that with your acceptance, because I understand you do accept it --

(13) [Claimant] It sets my teeth on edge, a lot of it.

[Judge] It is not going to bulk very large in my thinking.

[Claimant] Your Lordship knows how your Lordship is thinking but, with respect, I do not. You have a poker face and a complete mask like demeanour which keeps me totally in the dark. People ask me when I go home how have you done and I say I not know.

\subsubsection{Hope}

As already mentioned, the only regularity which seemed to emerge from an examination of patterns with second-person subjects was that they attracted volitive modality markers. The first of them, i.e., hope, was combined with the progressive to refer to the co-present speakers' hopes and desires, which gave them more prominence. This, however, was not coupled with their positive assessment. It may in fact be argued that the emphasis was added to confront and challenge the views presented by the opposing party (see 14 and 15).

(14) [Claimant] Do liars not deserve to be exposed as such? If you saw the audience as you saw them in that film, did you see any skinheads or extremists or people wearing arm bands? I did not. They looked like a perfectly ordinary bunch of middle-class Canadians.

[Counsel] No doubt they too, Mr Irving, will spread the word, if I may use that terminology?

[Claimant] Is that evidence or are you asking me a question?

[Counsel] I am asking you a question. That is what you are hoping, is it not? [Claimant] Spread the word that there are elements of the Holocaust story that need to be treated with scepticism, yes. 
(15) [Claimant] (...) Characteristically of the weakness of their case, Professor Funke listed one entry in a diary where I noted "road journey with a Thomas" whose second name I never learned; Funke entered the name “Dienel?” So for as I know, I have never met a Dienel, but it illustrates the kind of evidence that the Defence were hoping to rely upon. (...)

\subsubsection{Want}

Progressives with the second volitive marker found in the data, i.e., want, behaved quite differently. In this case, all occurrences with the second-person subject you (just like the progressive I am (just) wanting) were identified only in the judge's turns. It was also possible to see that they performed the interpretative function, additionally signaled by the preceding I think (see 16 and 17). One might even go further and suggest, in agreement with Prażmo (2018), that you are/were wanting integrated the meaning of the subject's 'desire or wish for something' and 'temporariness and relevance to the moment of speaking.' This made these progressives similar to the be going to structure, expressing not only the subject's desire but also his/her 'intention to act on that desire' (Prażmo 2018: 57). The examples found in the courtroom data corroborate this interpretation (cf. I am just wondering whether he is not wanting to go off somewhere else).

(16) [Claimant] You are saying here in an expert report which you now concede is written on rather flimsy evidence that Hitler personally -[Witness] I do not think I did that at all, Mr Irving.

[Claimant] - marked crosses against the names of scores of people?

[Judge] I think if you are wanting to say that there is documentary support for what you write, Mr Irving, and for what Professor Evans criticises, you really ought to be equipped to show Professor Evans what you rely on. For example, I mean, did you record what General Milsche was telling you about the absence of Hitler, and so on?....

(17) [Judge] May I interrupt you? Why do you not go back and then you can give the evidence that I think you were wanting to give before the adjournment about air raids in 1943. 


\subsubsection{Believe}

The last excerpt illustrates the progressive with believe. Of all stative verbs, the "intellectual state" verbs such as believe, suppose and know resist the progressive the most. In the data, only one combination of believe with the progressive form was identified and it is presented below (18). ${ }^{14}$ What can be seen here is, in fact, the juxtaposition of the progressive with the simple form (the people who are believing that the gas chambers were not used for homicidal purposes vs. the people who believed that they were used for homicidal purposes). It may well be the case that differentiating between the two forms, the witness implicitly evaluates the convictions held by the two groups of people. He seems to be assessing the beliefs held by the second group as more stable (and possibly rational) while indicating the temporary (and possibly reversible) nature of the beliefs represented by the first group. Though marginal, such uses lend support to the claim that the progressive construction is a marker of contingency.

(18) [Witness] It is difficult to say. It seems to be that the book buying habits of the people who are believing that the gas chambers were not used for homicidal purposes seems to have been much more active than for the people who believed that they were used for homicidal purposes. After all, I think that you sell more books than I sell of my Auschwitz books. [Claimant] Not currently I do not.

\subsection{Progressives of mental verbs versus progressives of communication verbs}

Finally, the study has also revealed that progressives with mental verbs are used differently from what earlier research says about progressives with the most common communication verbs say, talk, tell and speak (Szczyrbak 2018). The differences reflect the fact that while mental verbs entail "private (internal) domains of reference," communication verbs draw on "public (external) domains of reference" (Fetzer 2014: 70). This, in turn, translates into divergent patterns of use and varied discourse functions (Table 4).

14 The data also revealed one occurrence of the progressive with suppose and zero occurrences of the progressive with know. 
Table 4: Characterization of progressives in courtroom discourse.

Progressives with mental verbs (based on the
current study)

Not very frequent co-selection of mental verbs and the progressive form

Conventional meanings of mental verbs + their extensions

Add vividness, intensification, emphasis or, conversely, tentativeness and a lower degree of imposition

Co-occurrence with $I \rightarrow$ focus on the speaker's mental disposition/process of thinking/

epistemic position + temporariness/here-and-

now situation

Co-occurrence with you $\rightarrow$ interpretative use/

volitive modality (you are hoping, you are wanting)

Co-occurrence with third-person sub-

jects $\rightarrow$ interpretative use (mindsay)

Co-occurrence with modifiers

Most of the progressives used by the judge

Parenthetical use not attested

Switches between the simple and the progres-

sive form $\rightarrow$ describing vs. interpreting

(he assumes vs. he is not assuming)

Some of the verbs still resist the progressive

form: know, realize, believe, suppose, guess

(only the meaning of 'conjecture' found)
Progressives with communication verbs (based on Szczyrbak 2018)

Frequent co-selection of communication verbs and the progressive form

Conventional meanings of verbs describing communicative acts

Used for self- and other-reporting; discourse organization ("signposting"); epistemic/ evidential use + evaluative overtones

Co-occurrence with $I \rightarrow$ focus on the speaker's verbal performance/epistemic position + hereand-now situation

Co-occurrence with you $\rightarrow$ querying the response/negative evaluation of competitive narratives (are you saying/suggesting)

Co-occurrence with third-person subjects $\rightarrow$ interpretative use (hearsay) Co-occurrence with modifiers

Most of the progressives used by the opposing parties: the counsel and the claimant Parenthetical use attested

Switches between the simple and the progressive form $\rightarrow$ quoting/describing vs. interpreting (he talks vs. he is saying)

The first difference between the patterns reported in the current study and those described in Szczyrbak (2018) concerned the respective frequencies: communication verbs recurrently attracted the progressive form whereas the co-selection of mental verbs and the progressive was much rarer. As regards the discourse functions of the verbs, progressives with mental verbs foregrounded the speaker's perspective and they conveyed emphasis or, conversely, tentativeness. They specifically showed the relevance of the speaker's mental operations (thoughts, wishes and desires), and they were linked to epistemic and volitive modalities. ${ }^{15}$ Communication verbs, in turn, focused more on the speaker's or the addressee's linguistic performance, and they were frequently employed to restate (or reframe) earlier claims, or to challenge

15 Volitive modality is classified as a subcategory of deontic modality. 
alternative accounts. Both groups of progressives were interpretative; however, the difference lay in the patterns in which the verbs were found. Mental verbs were used chiefly in I-oriented declaratives (I am thinking) whereas communication verbs were frequent in you-oriented interrogatives (are you saying). Progressives with mental verbs were preferred by the presiding judge while progressives with communication verbs were favored by the opposing parties (the counsel and the claimant).

Another thing to note is that both groups of verbs co-occurred with modifiers; however, tentative qualifiers (still, quite, just) were co-selected with mental verbs rather than communication verbs. The syntactic realizations of the two groups of verbs differed as well. Namely, the comment clause status of progressives with communication verbs was frequent and it involved the qualification of the source of information (self vs. other). This was not the case with mental verbs, whose progressives were used predominantly for emphasis and intensification, rarely associated with parenthetical use. Finally, in both groups of verbs, switches between the simple form and the progressive form were evidenced (e.g., he assumes vs. he is not assuming; he talks vs. he is saying), bringing out the difference between a mere description (or a verbatim report) and the speaker's own evaluation.

\section{Discussion and conclusions}

The foregoing analysis shows that despite their relative infrequency, progressives with mental verbs provide insights into how participants in courtroom proceedings position themselves vis-à-vis other speakers and it also makes clear how their use differs from the use of communication verbs. At the same time, the study demonstrates that progressives are vehicles for subjective meanings which are not delivered by the simple form of verbs.

Overall, the analysis has revealed that the progressive of mental (or private) verbs was used predominantly by first-person subjects focusing on their thoughts, wishes and desires which were thus emphasized and given more prominence (e.g., I am hoping, I am wanting, I am understanding). The verbs wonder and think, it was found, were the most common choices: I was wondering performed the politeness function whereas I am thinking frequently indicated the act of cogitation. The "contingency" of progressives has also been evidenced, with some of the contextual readings going beyond the well-established meanings of individual verbs (e.g., whether he is not wanting to go off, people who are believing).

Furthermore, context-sensitivity and the role of speaker status (judge vs. other participants) emerged as significant factors affecting both the choice of verbs and their interactional configurations which differed, on the one hand, from the patterns involving the progressive of communication verbs and, on the other, from 
the patterns with the progressive of mental verbs found in other settings (e.g., media or online discourse). Noteworthy was, for instance, the absence of parenthetical progressives (e.g., ..., I'm thinking,...), “affective” progressives (e.g., I'm loving it) or the "intend" progressives referring to future plans (e.g., I'm thinking of going), which seems understandable given the institutional constraints of courtroom interaction. At the same time, other unconventional uses and meanings were attested, showing that trial discourse - despite the high degree of formality mirrors to some extent global trends visible in informal conversational contexts. ${ }^{16}$

All things considered, it should be reiterated that the English progressive - in its new incarnations and contexts of use - marks speaker stance and is increasingly subjective, which may be attributed to language change and the resultant extension of meanings of the $\mathrm{BE}+$-ing construction as well as a global shift towards more colloquial and less authoritarian communication. These trends - as the data at hand demonstrate - are making their way also into spoken legal communication, perhaps no longer validly described as conservative and resistant to change.

\section{References}

Aarts, Bas, Joanne Close, Geoffrey Leech \& Sean Wallis (eds.). 2013. The verb phrase in English. Investigating recent language change with corpora. Cambridge: Cambridge University Press.

Aijmer, Karin. 1997. I think - An English modal particle. In Toril Swan \& Olaf J. Westvik (eds.), Modality in Germanic languages: Historical and comparative perspectives, 1-47. Berlin \& New York: Mouton de Gruyter.

Aikhenvald, Alexandra Y. 2004. Evidentiality. Oxford: Oxford University Press.

Černá, Lucie. 2014. Re-evaluating the progressive form: The case of English verbs of attitude. In Michaela Martinková, Markéta Janebová \& Macháček Jaroslav (eds.), Categories and categorial changes: The third syntactical plan and beyond (Olomouc Modern Language Monographs 1), 114-125. Olomouc: Palacký University.

Chafe, Wallace L. \& Johanna Nichols (eds.). 1986 Evidentiality: The linguistic coding of epistemology. Norwood, NJ: Ablex.

De Wit, Astrid \& Brisard Frank. 2009. Expressions of epistemic contingency in the use of the English present progressive. Papers of the Linguistic Society of Belgium 4. 1-18.

De Wit, Astrid \& Brisard Frank. 2014. A cognitive grammar account of the semantics of the English present progressive. Journal of Linguistics 50(1). 49-90.

Du Bois, John W. 2007. The stance triangle. In Robert Englebretson (ed.), Stancetaking in discourse: Subjectivity, evaluation, interaction, 139-182. Amsterdam \& Philadelphia: John Benjamins.

16 The trial analyzed in the study took place in the year 2000, that is almost two decades ago. It may then be hypothesized that more recent courtroom data might yield more examples of nonaspectual progressives. 
Englebretson, Robert (ed.). 2007. Stancetaking in discourse: Subjectivity, evaluation, interaction. Amsterdam \& Philadelphia: John Benjamins.

Fetzer, Anita. 2014. I think, I mean and I believe in political discourse. Collocates, functions and distribution. Functions of Language 21(1). 67-94.

Finegan, Edward. 1995. Subjectivity and subjectivisation: An introduction. In Dieter Stein \& Susan Wright (eds.), Subjectivity and subjectivisation, 1-15. Cambridge: Cambridge University Press.

Freund, Nina. 2016. Recent change in the use of stative verbs in the progressive form in British English: l'm loving it. Language Studies Working Papers 7. 50-61.

Gibbons, John. 2005. Forensic linguistics: An introduction to language in the justice system. Malden, MA: Blackwell Publishing.

Granger, Sylviane \& Magali Paquot. 2008. Disentangling the phraseological web. In Sylviane Granger \& Fanny Meunier (eds.), Phraseology: An interdisciplinary perspective, 27-49. Amsterdam \& Philadelphia: John Benjamins.

Huddleston, Rodney \& Geoffrey K. Pullum. 2002. The Cambridge grammar of the English language. Cambridge: Cambridge University Press.

Hunston, Susan \& Geoff Thompson (eds.). 2000 Evaluation in text: Authorial stance and the construction of discourse. Oxford: Oxford University Press.

Hunston, Susan. 2011. Corpus approaches to evaluation. Phraseology and evaluative language. New York \& London: Routledge.

Hyland, Ken. 2005. Metadiscourse. London: Continuum.

Kaltenböck, Gunther. 2013. The development of comment clauses. In Bas Aarts, Joanne Close, Geoffrey Leech \& Sean Wallis (eds.), The verb phrase in English. Investigating recent language change with corpora, 286-317. Cambridge: Cambridge University Press.

Langacker, Ronald W. 1987. Foundations of cognitive grammar. Volume 1: Theoretical prerequisites. Redwood City, CA: Stanford University Press.

Leech, Geoffrey. 2004. Meaning and the English verb, 3rd edn. London: Longman.

Levin, Magnus. 2013. The progressive verb in American English. In Bas Aarts, Joanne Close, Geoffrey Leech \& Sean Wallis (eds.), The verb phrase in English. Investigating recent language change with corpora, 187-216. Cambridge: Cambridge University Press.

Mair, Christian \& Marianne Hundt. 1995. Why is the progressive becoming more frequent in English? Zeitschrift für Anglistik und Amerikanistik 43(2). 111-122.

Martin, James R. \& Peter R. White. 2003. The language of evaluation. London: Palgrave Macmillan. Martinez Vazquez, Montserrat. 2018. A corpus-based study of I am thinking in political speeches. Revista de Lenguas para Fines Específicos 24(2). 107-123.

Norén, Kerstin \& Per Linell. 2007. Meaning potentials and the interaction between lexis and contexts. An empirical substantiation. Pragmatics 17(3). 387-416.

Nuyts, Jan. 2001. Epistemic modality, language and conceptualization: A cognitive-pragmatic perspective. Amsterdam \& Philadelphia: John Benjamins.

Palmer, Frank R. 1986 [2001]. Mood and modality, 2nd edn. Cambridge: Cambridge University Press.

Potter, Simeon. 1975. Changing English. London: Andre Deutsch.

Prażmo, Ewelina. 2016. Unprecedented uses of the English present progressive. In Przemystaw Łozowski \& Katarzyna Stadnik (eds.), Visions and revisions. Studies in theoretical and applied linguistics (tódź Studies in Language 44), 169-178. Frankfurt am Main \& New York: Peter Lang. 
Prażmo, Ewelina. 2018. The modal potential in the English present progressive. Brno Studies in English 44(1). 43-62.

Quirk, Randolph, Sidney Greenbaum, Geoffrey Leech \& Svartvik Jan. 1985. A comprehensive grammar of the English language. London: Longman.

Römer, Ute. 2005. Progressives, patterns, pedagogy: A corpus-driven approach to English progressive forms, functions, contexts and didactics. Amsterdam \& Philadelphia: John Benjamins.

Scott, Mike. 2012. WordSmith Tools (version 6). Stroud: Lexical Analysis Software.

Smith, Carlota S. 1983. A theory of aspectual choice. Language 59. 479-501.

Szczyrbak, Magdalena. 2016. Say and stancetaking in courtroom talk: A corpus-assisted study. Corpora 11(2). 143-168.

Szczyrbak, Magdalena. 2018. Verba dicendi in courtroom interaction: Patterns with the progressive. In Stanistaw Goźdź-Roszkowski \& Gianluca Pontrandolfo (eds.), Phraseology in legal and institutional settings, 240-257. London \& New York: Routledge.

Traugott, Elizabeth C. \& Richard B. Dasher. 2002. Regularity in semantic change (Cambridge Studies in Linguistics 97). Cambridge: Cambridge University Press.

Verhagen, Arie. 2005. Constructions of intersubjectivity: Discourse, syntax, and cognition. Oxford: Oxford University Press.

Wierzbicka, Anna. 2006. English: Meaning and culture. Oxford: Oxford University Press.

Wright, Susan. 1995. Subjectivity and experiential syntax. In Dieter Stein \& Susan Wright (eds.), Subjectivity and subjectivisation, 151-172. Cambridge: Cambridge University Press.

\section{Sources}

Holocaust Denial on Trial. Trial transcripts. https://www.hdot.org/trial-materials/trialtranscripts/ (accessed 31 January 2013).

\section{Bionote}

\section{Magdalena Szczyrbak}

Institute of English Studies, Jagiellonian University, al. Mickiewicza 9a, 31-120, Kraków, Poland magdalena.szczyrbak@uj.edu.pl

https://orcid.org/0000-0002-0182-0938

Magdalena Szczyrbak is Assistant Professor at the Institute of English Studies, Jagiellonian University, Kraków, Poland. Her research interests are mainly in the areas of discourse analysis and Corpus-Assisted Discourse Studies applied to legal discourse and, in particular, to the study of stance and evaluation. Her current research focuses on mental and communication verbs and their role in marking stance in spoken legal genres. 